\title{
15. MAJOR-ELEMENT GEOCHEMISTRY OF ASHES FROM SITES 782, 784, AND 786 IN THE BONIN FOREARC ${ }^{1}$
}

\author{
R. J. Arculus ${ }^{2}$ and A. L. Bloomfield ${ }^{3}$
}

\begin{abstract}
Many ash-rich layers, varying from a few millimeters to several centimeters thick, were identified in the sedimentary sequences penetrated during Ocean Drilling Program Leg 125 at Sites 782, 784, and 786, located about 400 to $500 \mathrm{~km}$ south of Tokyo in the Bonin forearc. The total age range of the ash layers is from Eocene to Pleistocene, although not all sites cover this full span.

The ashes consist of vitric, microlite-bearing, and crystal-rich components; the glassy shards are typically highly vesicular, with elongate, flattened bubbles. The dominant crystalline phases are orthopyroxene, clinopyroxene, and plagioclase.

The major-element compositions of individual vitric shards collected from selected layers of Holes 782A, 784A, and 786A were determined by electron microprobe analyses; particular care was taken to ensure that the analytical results were not compromised by electron beam damage to the glasses.

Compositions range from basalt through andesite and dacite to rhyolite and generally belong to a tholeiitic, low-K suite. There is no indication of any regular secular change during the evolution of the Bonin arc from tholeiitic through calc-alkalic to alkalic compositions with time. In Holes 782A and 784A, some high-K rhyolite compositions of late Miocene and Pleistocene age are present. A clear chemical distinction has existed since arc inception between the source(s) of these ashes and the upper mantle source(s) tapped during construction of the igneous basement that formed the forearc.
\end{abstract}

\section{INTRODUCTION}

The results of a petrologic study of volcanic ash layers in EocenePleistocene sediments in the Izu-Bonin forearc are presented here. This study was undertaken to determine the petrogenetic character and evolutionary history of the explosive, subaerial magmatic activity of the Izu-Bonin arc system. Major-element compositions of volcanic glasses were determined; these were hand-picked from 36 selected ash layers recovered from the ODP Leg 125 Holes 782A, 784A, and $786 \mathrm{~A}$. These holes are located in the forearc region of the Bonin system, and some of the oldest ash layers recovered appear to be associated with the earliest stages of evolution of the arc.

Other scientists have studied similar ash layers recovered from the sedimentary cover in the Mariana Trough (Warner et al., 1987), however, the crust of this backarc basin is younger than that in the forearc, and consequently, the earliest history of the adjacent arc system is missing from the backarc ash record.

Holes 782A, 784A, and 786A are located 400 to $500 \mathrm{~km}$ south of Tokyo, about 50 to $100 \mathrm{~km}$ from the axis of the Izu-Bonin (Ogasawara) Trench and 50 to $120 \mathrm{~km}$ from the axis of the subaerially active volcanoes of the Izu-Bonin arc (Fig. 1). With respect to the nearest subaerial volcanoes, Sites 784 and 782 are southeast of Sumisu Jima and northeast of Torishima, while Site 786 is southeast of Aoga Shima. The ashes have been interpreted as the explosive eruptive products of an adjacent subaerial arc system, although, of course, the exact source of the ashes may not have been located along the currently active axis of the Izu-Bonin arc.

Some of the most significant results of this study (bearing in mind the sampling restriction to explosive fluxes only) include the following: (1) the compositions of the recovered ashes lie within a remarkably consistent compositional band; (2) the ash compositions are significantly different with respect to the Eocene-Oligocene forearc basement high (FBH; Honza and Tamaki, 1985), penetrated at Sites 782 and 786 (and also at Leg 126, Site 793); and (3) the current

\footnotetext{
'Fryer, P., Pearce, J. A., Stokking, L. B., et al., 1992. Proc. ODP, Sci. Results, 125: College Station, TX (Ocean Drilling Program)

Department of Geology and Geophysics, University of New England, Armidale, N.S.W. 2351, Australia.

${ }^{3}$ Department of Geological Sciences, University of Michigan, Ann Arbor, MI 48109 U.S.A.
}

volcanic rocks associated with the islands of Sumisu Jima and Torishima also appear to be distinctly different, compared with most of the Tertiary ash sequence.

Despite the disadvantage of sampling being restricted to the explosive component of arc activity, it is nevertheless true that only in the case of undisturbed, water-lain ash sequences can a fairly complete sequential record of subaerial volcanic activity be obtained. In contrast, lack of exposures or erosive gaps on volcanic edifices, coupled with deep burial of the earliest stages of igneous construction, limit our access to the record of geochemical evolution of the arc.

Another significant advantage for analyzing glass compositions compared with compositions of phyric lithologies, of course, is that glasses are directly representative of the liquid compositions and, consequently, are of great value for determining liquid lines of descent and processes of magmatic differentiation.

\section{SAMPLE DETAILS}

A total of 14 ash layers from Hole 782A, 10 layers from Hole 784A, and 12 layers from Hole 786A were examined. Ash layers selected for study either lack or have minimal evidence for bioturbation and reworking. Layers were chosen in an attempt to obtain a preliminary and temporally representative sample sequence, although we recognize that a large number of layers remain unstudied (e.g., 116 ash or ash-dominated layers are documented in Hole 782A, 86 in Hole $784 \mathrm{~A}$, and 58 in Hole 786A), and significant time gaps have not been studied to this point.

Biostratigraphic dating and magnetostratigraphy were combined to obtain estimates for the ages of the ash layers studied (Table 1). The ages for samples from Hole $782 \mathrm{~A}$ range from 0.3 to about $42 \mathrm{Ma}$; for Hole 784A from approximately 2.6 to $7 \mathrm{Ma}$; and for Hole 786A, from about 2.6 to about $43 \mathrm{Ma}$. At this point we have been unable to correlate any single layer across all three of the sites, nor examined possible thickness variations in specific horizons in an attempt to identify source directions.

\section{ANALYTICAL TECHNIQUES}

Individual shards were handpicked from the 5- to $10-\mathrm{cm}^{3}$, plastic-tube cores taken on board the ship. We endeavored to include as many different sizes, shapes (most are elongated and jagged externally), and colors 


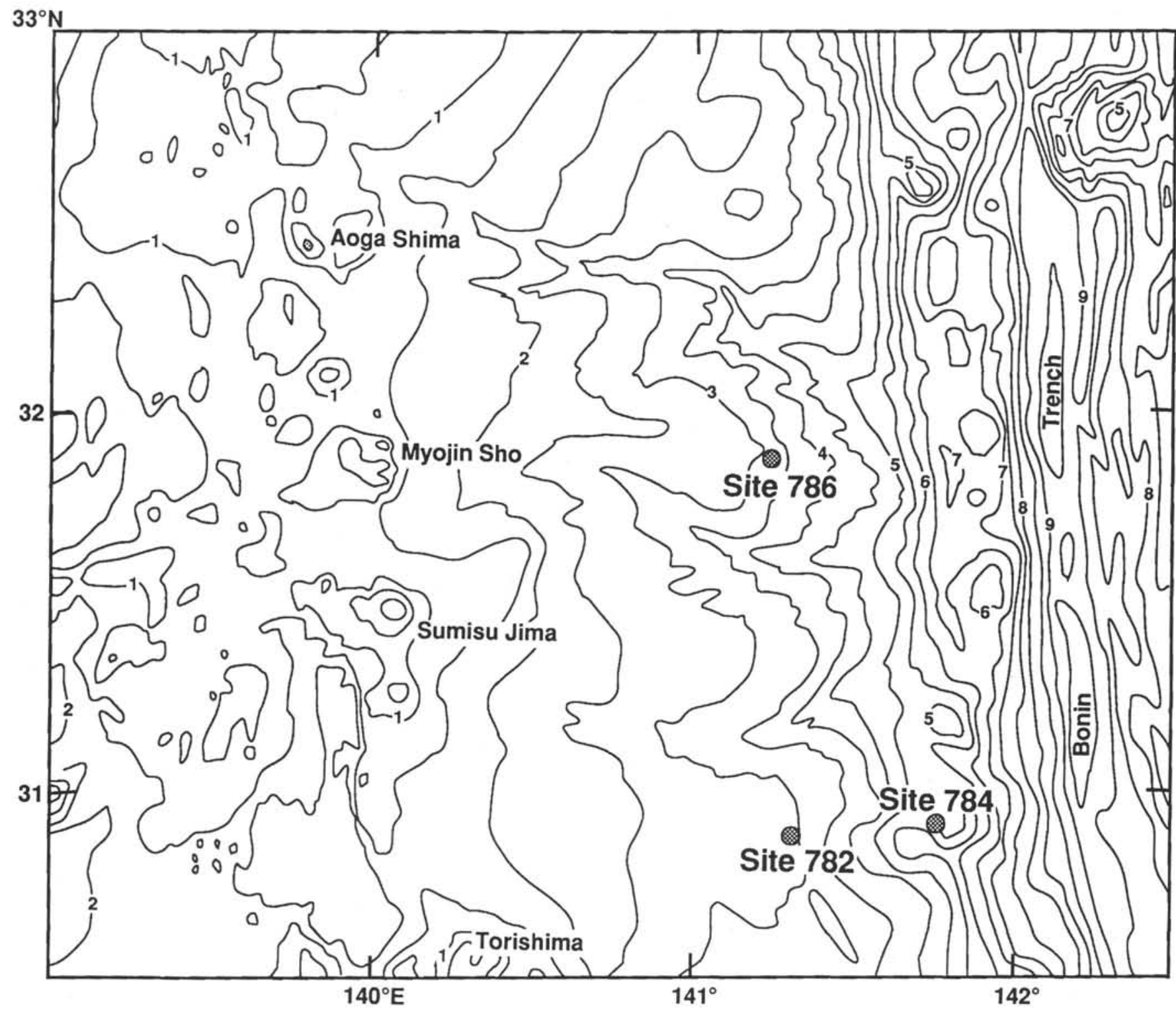

Figure 1. Location map of ODP Leg 125 Sites 782, 784, and 786, together with active subaerial volcanoes of the Bonin arc. Depths are in kilometers.

(almost colorless through pale yellow and varying shades of bottle green to greenish brown) of shards as possible in any given sample. These samples were washed in deionized water in an ultrasound bath, gently dried, mounted in perspex, and carefully polished.

The major-element chemistry of individual glass shards within ash layers was determined with the fully automated, 3-spectrometer Cameca Camebax electron microprobe located in the Electron Microbeam Analytical Laboratory at the University of Michigan. The great advantage of individual shard analysis is that the true degree of heterogeneity within a given layer can be determined, and genuinely magmatic compositions can be obtained that have been unsullied by background sediment contamination.

Because hydrated glasses are particularly susceptible to alkali metal loss during electron beam bombardment, analytical conditions were carefully selected to minimize this potential problem. Also taken into account is the tendency of silicon counts per second to increase with time during electron bombardment of glass.

Other scientists have shown that $\mathrm{Na}$ and $\mathrm{K}$ loss during electron beam bombardment of glass is minimized when high accelerating voltage, low-beam current, short counting times, and a rastered beam are used (Neilson and Sigurdsson, 1981; Strope, 1984; Jercinovic and Keil, 1988). A variety of analytical conditions were tested for their effectiveness in reducing $\mathrm{Na}$ and $\mathrm{K}$ loss in these glasses. The optimum operating conditions were determined as (1) $15-\mathrm{kV}$ accelerating voltage, (2) $5-\mathrm{nA}$ beam current with the beam rastered over an area of $15 \mu \mathrm{m} \times 15 \mu \mathrm{m}$. Beam rastering has the additional advantage of effectively averaging any micrometer-scale compositional heterogeneities.

Electron beam damage to the glass samples and alkali metal volatilization were minimized by using short counting times during analysis of the unknowns. Counts were collected for $5 \mathrm{~s}$ for $\mathrm{Na}, \mathrm{K}$, and $\mathrm{Si}$, which were analyzed first. Counts for $\mathrm{P}$ and $\mathrm{F}$ were then collected for $10 \mathrm{~s}, \mathrm{Ti}, \mathrm{Mn}$, and $\mathrm{Cl}$ for $15 \mathrm{~s}$, and finally $\mathrm{Mg}, \mathrm{Fe}, \mathrm{Ca}$, and $\mathrm{Al}$ for $20 \mathrm{~s}$. Natural mineral standards were used to calibrate the electron microprobe. Peak and background positions were occupied for 30 and 15 s respectively, on the standards.

Several basaltic and rhyolitic glass standards of known composition (USNM 111240/52 VG-2; USNM 113498/1 VG-A99; USNM 72843 VG-568) were analyzed prior to analysis of the Leg 125 samples to monitor the accuracy of our microprobe calibration. 
Table 1. Occurrence, depth, and age of ash layers.

\begin{tabular}{|c|c|c|c|}
\hline $\begin{array}{l}\text { Core, section } \\
\text { Interval }(\mathrm{cm})\end{array}$ & $\begin{array}{l}\text { Depth } \\
\text { (mbsf) }\end{array}$ & $\begin{array}{l}\text { Age } \\
\text { (Ma) }\end{array}$ & $\begin{array}{c}\text { Shipboard } \\
\text { layer no. }\end{array}$ \\
\hline \multicolumn{4}{|l|}{$125-782 \mathrm{~A}=$} \\
\hline $1 \mathrm{H}-3,22-24$ & 3.2 & $<0.3$ & 2 \\
\hline $2 \mathrm{H}-6,84-87$ & 18.1 & $0.3-1.6$ & 12 \\
\hline $6 \mathrm{H}-1,138-140$ & 47.9 & $\sim 2.0$ & - \\
\hline $11 X-3,51-54$ & 99.2 & -3 & 29 \\
\hline $13 X-2,104-106$ & 117.5 & $3.6-4.6$ & 35 \\
\hline $13 X-3,52-54$ & 118.5 & $3.6-4.6$ & 36 \\
\hline $14 X-2,113-115$ & 127.3 & $3.6-4.6$ & 39 \\
\hline $14 X-2,141-143$ & 127.5 & $3.6-4.6$ & 40 \\
\hline $15 X-4,15-17$ & 139 & $3.6-4.6$ & 40 \\
\hline $17 X-2,123-125$ & 156.3 & $4.6-6.5$ & 54 \\
\hline $17 X-5,140-142$ & 161.0 & $4.6-6.5$ & 58 \\
\hline $26 \mathrm{X}-1,141-144$ & 241.7 & $\sim 9.0$ & 89 \\
\hline $29 \mathrm{X}-6,39-41$ & 277.0 & $10.2-10.5$ & 99 \\
\hline $41 X-C C, 44-47$ & 385 & -42 & - \\
\hline \multicolumn{4}{|l|}{$125-784 \mathrm{~A}-$} \\
\hline $8 R-5,35-37$ & 65 & 2.6 & 30 \\
\hline $9 R-1,69-71$ & 69 & 2.8 & 36 \\
\hline $10 \mathrm{R}-3,29-31$ & 81 & 3.2 & 37 \\
\hline $12 \mathrm{R}-2,66-68$ & 99 & 4.0 & 38 \\
\hline $16 \mathrm{R}-4,103-105$ & 141 & 5.6 & 54 \\
\hline $17 \mathrm{R}-3,144-149$ & 150 & 6.0 & 58 \\
\hline $17 R-4,38-40$ & 150.5 & 6.0 & 59 \\
\hline $18 \mathrm{R}-2,32-35$ & 157 & 6.3 & 63 \\
\hline $18 \mathrm{R}-2,102-104$ & 158 & 6.3 & 64 \\
\hline $20 \mathrm{R}-3,67-69$ & 178 & 7.1 & 74 \\
\hline \multicolumn{4}{|l|}{$125-786 \mathrm{~A}-$} \\
\hline $1 \mathrm{H}-4,23-25$ & 4.7 & -2.6 & 5 \\
\hline $5 X-1,74-76$ & 39 & -6.5 & 33 \\
\hline $6 X-3,126-128$ & 52 & $\sim 10$ & 41 \\
\hline $6 X-5,7-9$ & 53.7 & $\sim 10$ & 42 \\
\hline $6 X-5,39-41$ & 54 & -10 & 44 \\
\hline $7 X-2,127-129$ & 60 & $10-14$ & 46 \\
\hline $7 X-3,15-17$ & 60.2 & $10-14$ & 48 \\
\hline $7 X-5,64-66$ & 63 & $10-14$ & 52 \\
\hline $9 X-3,129-131$ & 81 & $14-24$ & 56 \\
\hline $9 X-4,24-26$ & 81.5 & $14-24$ & 57 \\
\hline $9 X-5,61-63$ & 83 & $14-24$ & 68 \\
\hline $19 \mathrm{X}-\mathrm{CC}$ & & -43 & - \\
\hline
\end{tabular}

Successful reproduction of the published values for the glass standards, within analytical uncertainty, indicates that the measurement technique used yields accurate chemical analyses for these samples.

Microprobe totals obtained for the glasses range from $92 \%$ to $100 \%$. The low totals may reflect in part the results of postdepositional hydration of the glasses. Although some water may have been magmatic, the volatile content (as estimated from some of the oxide total deficiencies) apparently exceeds that soluble in a magma of the observed composition (Clemens, 1984; see also Newman and van der Laan, this volume). Furthermore, many of the glass shards have textures indicative of exsolution of volatiles (vesicles or bubble wall morphologies); thus it is unlikely that the glasses have retained large amounts of pristine magmatic volatiles. Clearly, spectroscopic studies of the abundances and speciation of the volatile complement should be appropriate.

For ease of intersample comparison, the analyses have been recalculated to $100 \%$ on a volatile-free basis, and these data are presented in Table 2 . The relatively short counting times result in fairly large analytical uncertainties for individual analyses. To reduce these uncertainties, replicate analyses taken within individual shards were averaged. In some cases, averages were taken of measurements from different shards (within a single ash layer) if the compositions of the shards were within analytical precision for $\mathrm{Si}, \mathrm{Mg}, \mathrm{Fe}$, and $\mathrm{Ca}$. The number of analyses averaged are also reported in Table 2. Note that the shards in ash layers from Hole 784A generally exhibit greater compositional variation than those in Holes
$782 \mathrm{~A}$ or $786 \mathrm{~A}$, so that the majority of the measurements for ashes from Hole 784A were not averaged.

\section{PETROGRAPHY OF GLASSES AND PHENOCRYSTS}

The glass fragments in the ash layers range in size from less than $1 \mathrm{~mm}$, to $5 \mathrm{~mm}$ in maximum dimension. They are variably vesicular and are remarkably fresh throughout the sequences from all three of the holes, even those sequences from the early Miocene. Some progressive devitrification and palagonitization is apparent in samples from Oligocene through Eocene, but even in these some apparently fresh material remains. Whether, in fact, these samples are pristine with respect to fluid exchange with surrounding sediments remains undetermined. The hydration suggested by microprobe totals that reach a minimum of $92 \%$ is not evident optically in thin section.

The degree of crystallinity of the glasses is variable, even within a single ash layer. Some ash layers are dominated by glass shards without microlites; others are composed of glass fragments having a significant microlite content. Some layers contain both crystal-free shards and others having numerous crystallites, but there is no clear compositional distinction that has yet been recognized between the crystal-free or crystal-rich shards. However, because of the difficulty in obtaining accurate chemical data by microprobe analysis of highly inhomogeneous (microlite-rich) material, only data from crystal-poor shards are presented here.

Many of the ash layers contain individual crystals. Most layers contain plagioclase, but pyroxene also is fairly common. Pyroxene compositions are presented in Table 3 and are projected in terms of $\mathrm{Mg}-\mathrm{Fe}-\mathrm{Ca}$ components in Figure 2. Some individual ash layers contain glass shards having a range of compositions, so it was not always possible to discern from which melt a particular crystal or crystalline assemblage had been derived. Consequently, pyroxene compositions were determined only for crystals occurring in apparently homogeneous layers. Nevertheless, the range of pyroxene compositions obtained suggests that these layers may contain more than one vitric and crystal ash population.

\section{DISCUSSION}

The major-element compositions of the ashes studied form a tight continuum from basalt to rhyolite. This compositional range is of tholeiitic (Fig. 3), low-K character. Ashes analyzed from Hole 782A range from 53.1 to 78 weight $\%$ (wt $\%) \mathrm{SiO}_{2}$, those from Hole $784 \mathrm{~A}$ range from 50.2 to $77.6 \mathrm{wt} \% \mathrm{SiO}_{2}$, and those from 786A range from 47.6 to $76.3 \mathrm{wt} \% \mathrm{SiO}_{2}$. The $\mathrm{MgO}$ contents of ashes from these holes ranges from 5.8 to $0.04 \mathrm{wt} \%$ in Hole $782 \mathrm{~A}$, from 6.1 to $0.02 \mathrm{wt} \%$ in Hole $784 \mathrm{~A}$, and from 8.8 to $0.4 \mathrm{wt} \%$ in Hole $786 \mathrm{~A}$.

Many of the compositional ranges of the ashes from the three holes overlap when the analyses of all of them are plotted together (Fig. 4). As is evident in these variation diagrams, for oxides such as $\mathrm{CaO}, \mathrm{FeO} *$ (total $\mathrm{Fe}$ as $\mathrm{FeO}$ ), $\mathrm{MgO}$, to a lesser extent $\mathrm{Na}_{2} \mathrm{O}$, and for a subset for $\mathrm{K}_{2} \mathrm{O}$, glass compositions are tightly grouped and appear to vary systematically. Some oxides vary linearly with silica (e.g., $\mathrm{CaO}$ ) but others, such as $\mathrm{MgO}$, vary nonlinearly (Fig. 4). We interpret the distinctly nonlinear variation of $\mathrm{MgO}$ with $\mathrm{SiO}_{2}$ to indicate that the genesis of the spectrum of glass (melt) compositions sampled was dominated by fractional crystallization rather than simple mixing processes.

There is more relative scatter of oxide variation in the case of $\mathrm{Al}_{2} \mathrm{O}_{3}, \mathrm{TiO}_{2}, \mathrm{MnO}$, and particularly $\mathrm{F}$ and $\mathrm{Cl}$. In the case of the minor components, part of this scatter can reasonably be attributed to the degree of precision of electron microprobe analyses at low concentration levels with relatively short counting times. The scatter in $\mathrm{Al}_{2} \mathrm{O}_{3}$ should be free of this type of analytical noise and, given that these are glass compositions, appears to indicate that differing degrees of plagioclase fractionation were involved in the parental magmas. Note that within the trend of $\mathrm{Al}_{2} \mathrm{O}_{3}$ variation with $\mathrm{SiO}_{2}$, there is about $16 \mathrm{wt} \% \mathrm{Al}_{2} \mathrm{O}_{3}$ at about $54-57 \mathrm{wt} \% \mathrm{SiO}_{2}$. 


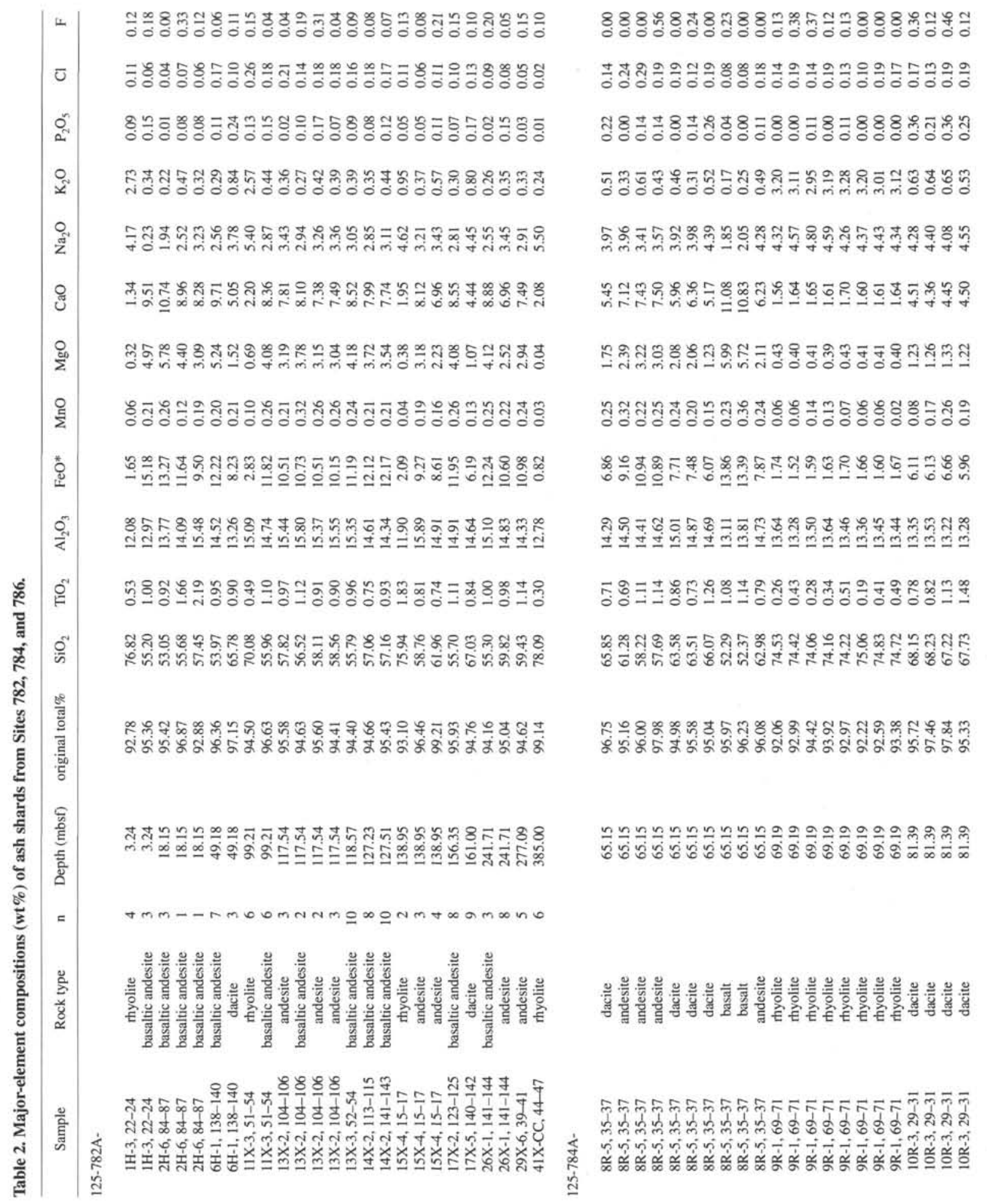

Projections of the glass compositions in the olivine-clinopyroxenequartz pseudoternary phase diagram of Grove et al. (1982) are shown in Figure 5 . The glass compositions generally overlap closely the $10^{5}-\mathrm{Pa}$ cotectics of this projection; thus a possible interpretation is that the overall compositional spread results from fractional crystallization differentiation at very low pressures in shallow crustal-level magma chambers. However, the opposing effects of equilibrium pressures of differentiation $\left(>10^{5} \mathrm{~Pa}\right.$ ) and elevated $\mathrm{H}_{2} \mathrm{O}$ activities on the position of the appropriate cotectics means that other conditions are possible, and that this overlap may be coincidental. Quantification of the pristine volatile contents will help to resolve this question.

It is clear in detail that the glass compositions cannot represent a single line of liquid descent because (1) the ash layers are probably not the products of one volcanic center; (2) the ages of the layers range over a 


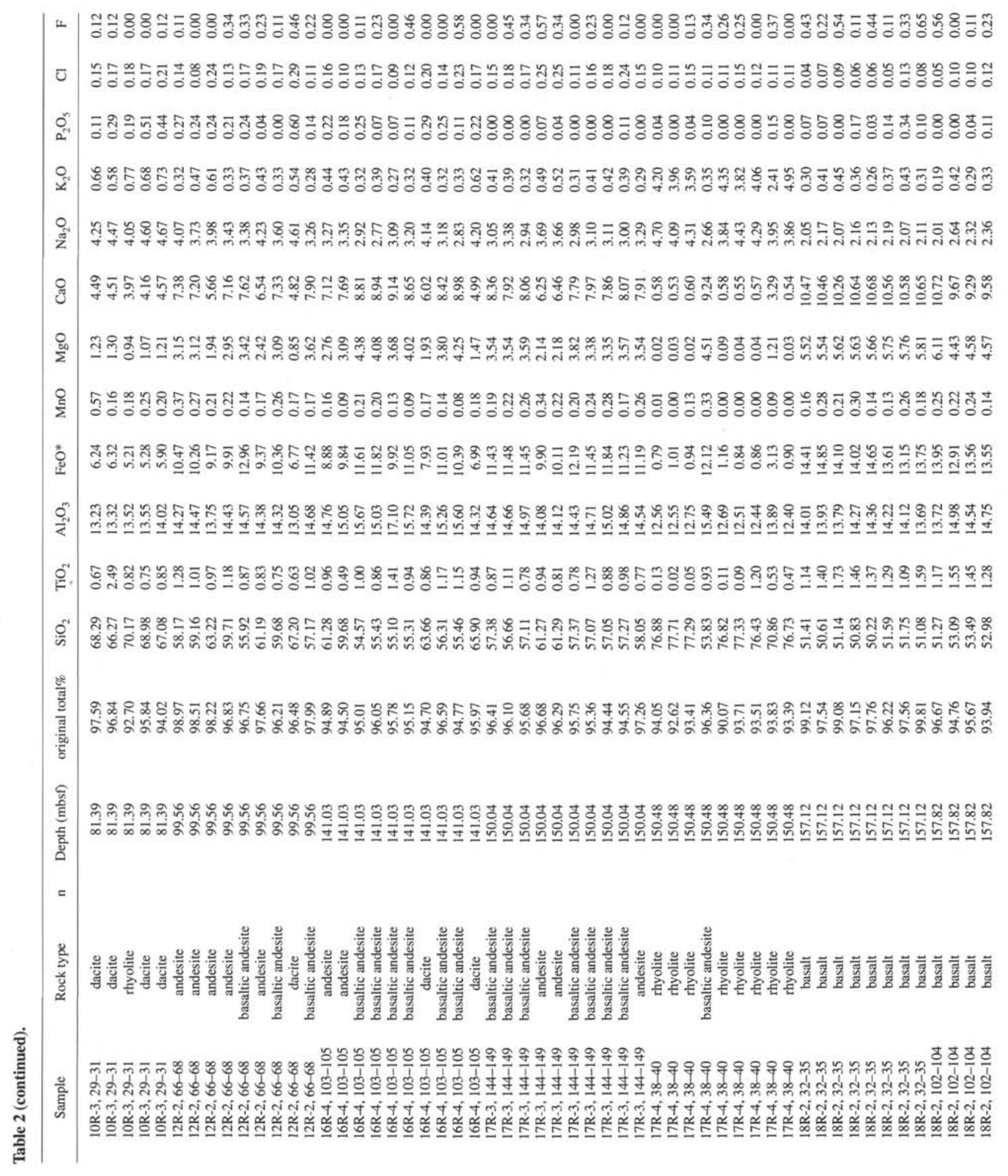

period of about $40 \mathrm{Ma}$; and (3) the temporal relationships between the various compositions are inconsistent with a single evolutionary progression from low-to high-silica magmas (see Fig. 6).

Nevertheless, the compositional variation documented may have resulted from the oft-repeated eruption of lavas that formed by a common differentiation process, persistently reproduced, possibly in more than one magmatic system, over a remarkable period of time. Note that we see no evidence for a secular change in the geochemistry of these ash horizons taken in toto, and no hint of the production of more calc-alkaline or even alkaline compositions as the Izu-Bonin arc system has matured.

No clear relationship exists between the composition and age of the ash layers (Fig. 6). High- and low-silica glasses occur throughout the ash sequences, with no discernible order apparent at this stage of our studies. In some cases, individual ash layers contain glass shards having a range of compositions. The compositional heterogeneity within what were originally interpreted as individual ash layers may reflect eruption of a compositionally layered magma chamber. An 


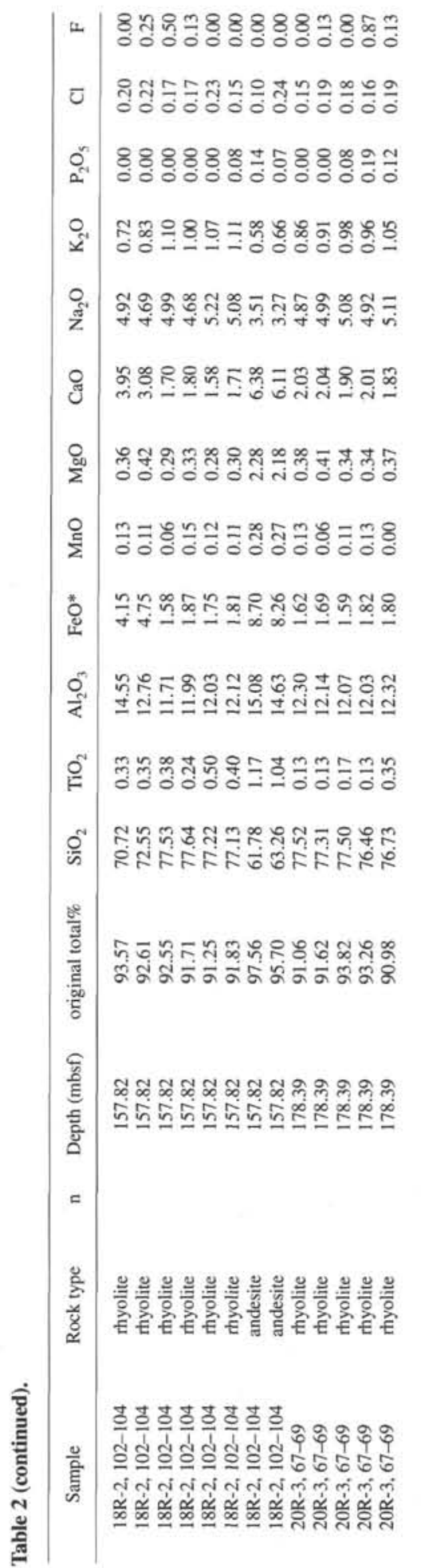

alternative explanation is that ash eruptions from more than one volcano occurred within a relatively short period of time and that some degree of bioturbation and reworking of the ash layers mixed the different ashes together.

$\mathrm{K}_{2} \mathrm{O}$-rich compositions occur in Hole $784 \mathrm{~A}$ in Cores 9 (about 69 meters below sea floor (mbsf) and $2.8 \mathrm{Ma}$ old) and 17 (about $150 \mathrm{mbsf}$ and $6 \mathrm{Ma}$ old), and in Hole 782A in Cores 1 (at about $3 \mathrm{mbsf}$ and $<0.3 \mathrm{Ma}$ old) and 11 in a bimodal population (at $99 \mathrm{mbsf}$, approx. $3 \mathrm{Ma}$ old). We are not convinced that the high- $\mathrm{K}_{2} \mathrm{O}$ layers in Samples

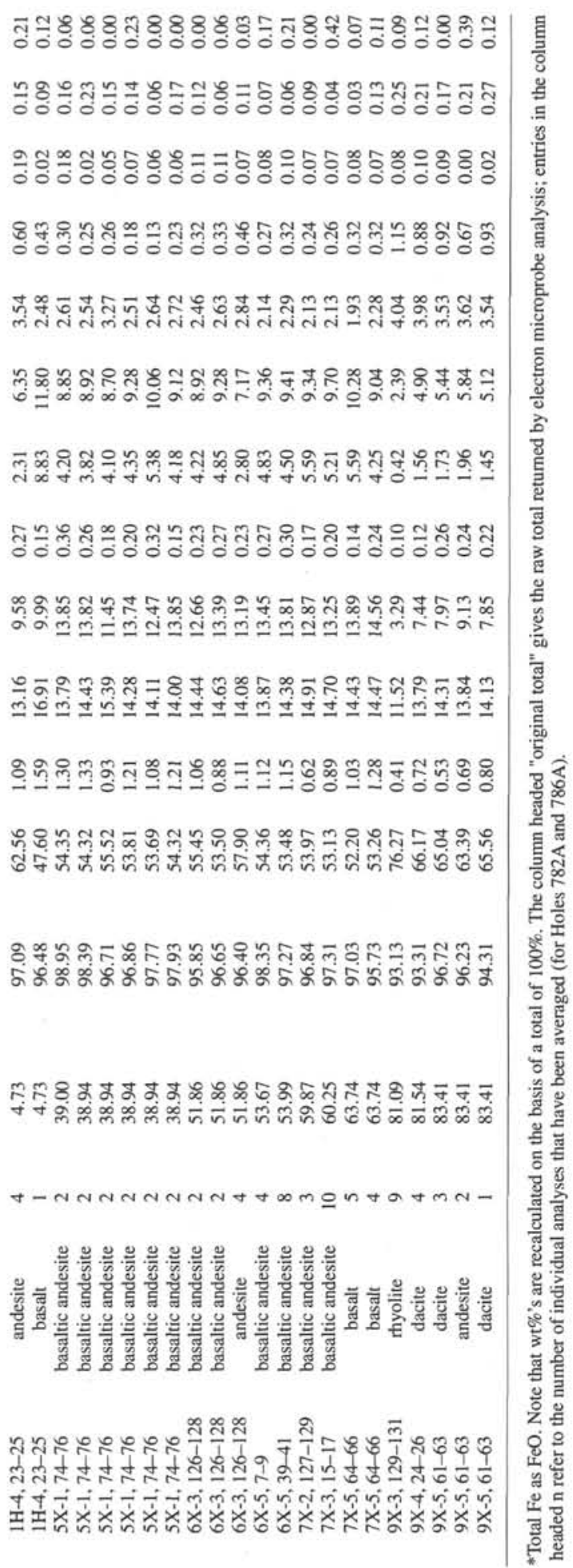

125-784A-9R-1, 69-71 cm, and 125-782A-11X-3, 51-54 cm, are correlated. These compositions are clearly distinct with respect to the rest of the suite and have not yet been detected in Hole 786A.

Note that the wide range in major-element compositions within individual ash layers is evidence that analysis of individual glass shards is a more accurate measure of original lava composition than are bulk ash analyses. Furthermore, future application of any method of trace-element analysis must take this heterogeneity into account, and one should take great care to analyze homogeneous glass populations. 

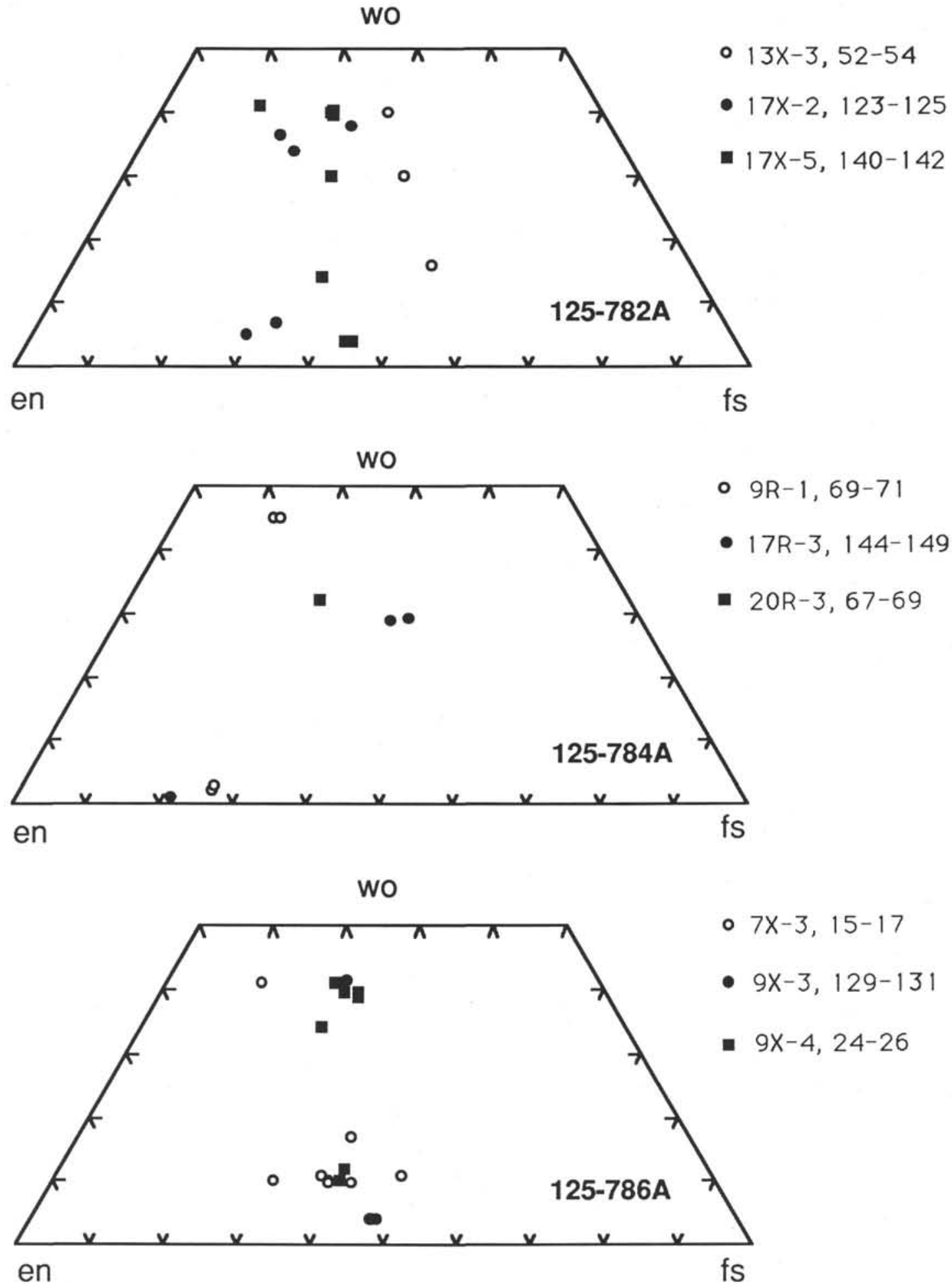

Figure 2. Projections of pyroxene compositions in terms of relative proportions of $\mathrm{Ca}-\mathrm{Mg}-\mathrm{Fe}$, separated by site. Sample numbers are given. 
Table 3. Representative pyroxene compositions.

\begin{tabular}{|c|c|c|c|c|c|c|c|c|c|c|}
\hline A & column 1 & column 2 & column 3 & column 4 & column 5 & column 6 & column 7 & column 8 & column 9 & column 10 \\
\hline $\mathrm{SiO}_{2}$ & 50.47 & 49.03 & 49.17 & 51.67 & 45.39 & 52.88 & 50.20 & 50.12 & 51.55 & 51.36 \\
\hline $\mathrm{TiO}_{2}$ & 0.25 & 0.39 & 0.55 & 0.23 & 1.65 & 0.23 & 0.39 & 0.49 & 0.24 & 0.53 \\
\hline $\mathrm{Al}_{2} \mathrm{O}_{3}$ & 1.05 & 1.18 & 1.69 & 1.15 & 7.72 & 1.16 & 2.29 & 2.57 & 0.67 & 1.38 \\
\hline $\mathrm{Cr}_{2} \mathrm{O}_{3}$ & 0.03 & 0.00 & 0.00 & 0.04 & 0.00 & 0.00 & 0.03 & 0.02 & 0.00 & 0.00 \\
\hline $\mathrm{FeO}$ & 18.36 & 28.25 & 22.31 & 19.39 & 15.01 & 18.57 & 12.86 & 11.38 & 26.93 & 14.27 \\
\hline $\mathrm{MnO}$ & 0.84 & 0.53 & 0.50 & 0.48 & 0.34 & 0.4 & 0.34 & 0.32 & 0.81 & 0.55 \\
\hline $\mathrm{MgO}$ & 9.83 & 11.54 & 10.39 & 20.91 & 10.85 & 23.34 & 15.67 & 15.61 & 17.58 & 12.46 \\
\hline $\mathrm{CaO}$ & 18.79 & 7.31 & 13.61 & 3.58 & 16.46 & 2.25 & 16.35 & 17.51 & 1.88 & 19.32 \\
\hline $\mathrm{Na}_{2} \mathrm{O}$ & 0.16 & 0.08 & 0.18 & 0.04 & 0.40 & 0.01 & 0.16 & 0.16 & 0.02 & 0.22 \\
\hline \multirow[t]{2}{*}{ Total } & 99.80 & 98.31 & 98.40 & 97.50 & 97.82 & 98.83 & 98.29 & 98.18 & 99.95 & 100.09 \\
\hline & column 11 & column 12 & column 13 & column 14 & column 15 & column 16 & column 17 & column 18 & column 19 & column 20 \\
\hline $\mathrm{SiO}_{2}$ & 51.18 & 50.97 & 51.59 & 51.96 & 51.06 & 50.31 & 51.29 & 51.16 & 52.96 & 53.57 \\
\hline $\mathrm{TiO}_{2}$ & 0.28 & 0.48 & 0.44 & 0.35 & 0.44 & 0.57 & 0.26 & 0.41 & 0.21 & 0.23 \\
\hline $\mathrm{Al}_{2} \mathrm{O}_{3}$ & 0.78 & 1.33 & 1.25 & 1.95 & 1.33 & 1.70 & 1.34 & 2.00 & 0.90 & 0.93 \\
\hline $\mathrm{Cr}_{2} \mathrm{O}_{3}$ & 0.02 & 0.03 & 0.00 & 0.15 & 0.00 & 0.00 & 0.00 & 0.01 & 0.00 & 0.00 \\
\hline $\mathrm{FeO}$ & 26.24 & 14.45 & 14.41 & 8.37 & 21.15 & 16.75 & 7.91 & 8.79 & 16.80 & 16.66 \\
\hline $\mathrm{MnO}$ & 0.86 & 0.48 & 0.51 & 0.21 & 0.60 & 0.48 & 0.42 & 0.50 & 0.64 & 0.56 \\
\hline $\mathrm{MgO}$ & 17.95 & 12.66 & 12.61 & 16.42 & 17.45 & 14.23 & 14.71 & 14.25 & 25.59 & 25.52 \\
\hline $\mathrm{CaO}$ & 2.01 & 19.25 & 19.02 & 20.10 & 6.83 & 14.21 & 21.90 & 21.77 & 1.24 & 1.27 \\
\hline $\mathrm{Na}_{2} \mathrm{O}$ & 0.01 & 0.20 & 0.21 & 0.13 & 0.11 & 0.23 & 0.32 & 0.36 & 0.03 & 0.04 \\
\hline \multirow[t]{2}{*}{ Total } & 99.33 & 99.85 & 100.03 & 99.63 & 98.97 & 98.47 & 98.15 & 99.26 & 98.37 & 98.76 \\
\hline & column 21 & column 22 & column 23 & column 24 & column 25 & column 26 & column 27 & column 28 & column 29 & column 30 \\
\hline $\mathrm{SiO}_{2}$ & 55.03 & 54.47 & 48.94 & 51.15 & 49.27 & 50.16 & 50.04 & 51.03 & 51.10 & 50.50 \\
\hline $\mathrm{TiO}_{2}$ & 0.33 & 0.30 & 0.11 & 0.02 & 0.53 & 0.23 & 0.24 & 0.19 & 0.30 & 0.35 \\
\hline $\mathrm{Al}_{2} \mathrm{O}_{3}$ & 1.80 & 1.86 & 4.50 & 2.47 & 2.44 & 0.94 & 0.99 & 0.96 & 0.91 & 0.99 \\
\hline $\mathrm{Cr}_{2} \mathrm{O}_{3}$ & 0.03 & 0.00 & 0.00 & 0.00 & 0.04 & 0.00 & 0.00 & 0.00 & 0.00 & 0.00 \\
\hline $\mathrm{FeO}$ & 14.22 & 13.86 & 20.61 & 19.72 & 15.94 & 22.26 & 22.85 & 23.43 & 25.17 & 23.34 \\
\hline $\mathrm{MnO}$ & 0.28 & 0.29 & 1.22 & 1.19 & 0.47 & 0.66 & 0.57 & 0.63 & 0.74 & 0.69 \\
\hline $\mathrm{MgO}$ & 28.76 & 28.90 & 9.30 & 10.30 & 14.46 & 18.55 & 17.94 & 18.38 & 17.14 & 16.03 \\
\hline $\mathrm{CaO}$ & 0.51 & 0.46 & 12.10 & 12.20 & 15.16 & 5.10 & 4.88 & 4.86 & 4.62 & 8.28 \\
\hline $\mathrm{Na}_{2} \mathrm{O}$ & 0.02 & 0.01 & 0.32 & 0.19 & 0.20 & 0.06 & 0.08 & 0.06 & 0.07 & 0.13 \\
\hline \multirow[t]{2}{*}{ Total } & 100.97 & 100.15 & 97.09 & 97.25 & 98.52 & 97.96 & 97.60 & 99.54 & 100.04 & 100.29 \\
\hline & column 31 & column 32 & column 33 & column 34 & column 35 & column 36 & column 37 & column 38 & column 39 & column 40 \\
\hline $\mathrm{SiO}_{2}$ & 51.90 & 52.11 & 50.26 & 50.31 & 50.60 & 50.42 & 50.47 & 50.14 & 50.64 & 50.81 \\
\hline $\mathrm{TiO}_{2}$ & 0.22 & 0.23 & 0.38 & 0.19 & 0.19 & 0.27 & 0.27 & 0.23 & 0.27 & 0.51 \\
\hline $\mathrm{Al}_{2} \mathrm{O}_{3}$ & 2.29 & 1.59 & 0.79 & 0.53 & 0.53 & 0.93 & 1.05 & 0.65 & 1.05 & 3.07 \\
\hline $\mathrm{Cr}_{2} \mathrm{O}_{3}$ & 0.17 & 0.04 & 0.06 & 0.00 & 0.00 & 0.01 & 0.00 & 0.03 & 0.04 & 0.00 \\
\hline $\mathrm{FeO}$ & 8.51 & 18.61 & 28.45 & 28.54 & 28.23 & 14.77 & 15.03 & 28.52 & 14.87 & 14.65 \\
\hline $\mathrm{MnO}$ & 0.28 & 0.44 & 0.72 & 0.94 & 0.79 & 0.49 & 0.56 & 0.95 & 0.48 & 0.52 \\
\hline $\mathrm{MgO}$ & 16.22 & 21.12 & 14.38 & 17.07 & 16.97 & 11.77 & 12.01 & 16.57 & 12.13 & 14.07 \\
\hline $\mathrm{CaO}$ & 20.03 & 5.14 & 5.13 & 1.84 & 1.80 & 19.80 & 19.53 & 1.84 & 19.47 & 16.22 \\
\hline $\mathrm{Na}_{2} \mathrm{O}$ & 0.16 & 0.07 & 0.07 & 0.00 & 0.03 & 0.24 & 0.24 & 0.07 & 0.21 & 0.20 \\
\hline \multirow[t]{2}{*}{ Total } & 99.80 & 99.35 & 100.24 & 99,42 & 99.14 & 98.71 & 99.17 & 98.99 & 99.17 & 100.06 \\
\hline & column 41 & column 42 & column 43 & column 44 & column 45 & column 46 & & & & \\
\hline $\mathrm{SiO}_{2}$ & 47.38 & 47.01 & 51.68 & 51.21 & 46.01 & 45.56 & & & & \\
\hline $\mathrm{TiO}_{2}$ & 0.94 & 1.00 & 0.28 & 0.27 & 1.20 & 1.27 & & & & \\
\hline $\mathrm{Al}_{2} \mathrm{O}_{3}$ & 6.16 & 6.36 & 1.47 & 1.38 & 7.17 & 7.19 & & & & \\
\hline $\mathrm{Cr}_{2} \mathrm{O}_{3}$ & 0.01 & 0.00 & 0.00 & 0.00 & 0.00 & 0.00 & & & & \\
\hline $\mathrm{FeO}$ & 13.87 & 14.87 & 23.72 & 24.06 & 16.12 & 15.68 & & & & \\
\hline $\mathrm{MnO}$ & 0.36 & 0.40 & 0.77 & 0.77 & 0.34 & 0.28 & & & & \\
\hline $\mathrm{MgO}$ & 11.81 & 11.91 & 17.10 & 17.74 & 11.52 & 11.22 & & & & \\
\hline $\mathrm{CaO}$ & 19.01 & 18.48 & 5.61 & 4.57 & 18.14 & 18.30 & & & & \\
\hline $\mathrm{Na}_{2} \mathrm{O}$ & 0.25 & 0.26 & 0.08 & 0.05 & 0.20 & 0.21 & & & & \\
\hline Total & 99.79 & 100.30 & 100.73 & 100.06 & 100.70 & 99.71 & & & & \\
\hline
\end{tabular}


Table 3 (continued).

\begin{tabular}{|c|c|c|c|c|c|c|c|c|c|c|}
\hline B & column 1 & column 2 & column 3 & column 4 & column 5 & column 6 & column 7 & column 8 & column 9 & column 10 \\
\hline$\# \mathrm{Si}^{4+}$ & 1.958 & 1.962 & 1.946 & 1.969 & 1.760 & 1.968 & 1.904 & 1.897 & 1.975 & 1.948 \\
\hline$\# \mathrm{Ti}^{4+}$ & 0.007 & 0.012 & 0.016 & 0.007 & 0.048 & 0.007 & 0.011 & 0.014 & 0.007 & 0.015 \\
\hline$\# \mathrm{Al}^{3+}$ & 0.048 & 0.056 & 0.079 & 0.052 & 0.353 & 0.051 & 0.102 & 0.114 & 0.030 & 0.062 \\
\hline$\# \mathrm{Cr}^{3+}$ & 0.001 & 0.000 & 0.000 & 0.001 & 0.000 & 0.000 & 0.001 & 0.001 & 0.000 & 0.000 \\
\hline$\# \mathrm{Fe}^{2+}$ & 0.596 & 0.945 & 0.738 & 0.618 & 0.487 & 0.578 & 0.408 & 0.360 & 0.863 & 0.453 \\
\hline$\# \mathrm{Mn}^{2+}$ & 0.028 & 0.018 & 0.017 & 0.016 & 0.011 & 0.013 & 0.011 & 0.010 & 0.026 & 0.018 \\
\hline$\# \mathrm{Mg}^{2+}$ & 0.569 & 0.688 & 0.613 & 1.188 & 0.627 & 1.294 & 0.886 & 0.881 & 1.020 & 0.704 \\
\hline $\mathrm{HCa}^{2+}$ & 0.781 & 0.313 & 0.577 & 0.146 & 0.684 & 0.090 & 0.664 & 0.710 & 0.077 & 0,785 \\
\hline$\# \mathrm{Na}^{\mathrm{l+}}$ & 0.012 & 0.006 & 0.014 & 0.003 & 0.030 & 0.000 & 0.012 & 0.012 & 0.002 & 0.016 \\
\hline \#TOTAL & 4.000 & 4.000 & 4.000 & 4.000 & 4.000 & 4.000 & 4.000 & 4.000 & 4.000 & 4.000 \\
\hline$\Sigma \mathrm{MgFeCa}^{2+}$ & 1.946 & 1.946 & 1.928 & 1.952 & 1.798 & 1.962 & 1.959 & 1.951 & 1.960 & 1.941 \\
\hline En & 0.292 & 0.354 & 0.318 & 0.609 & 0.349 & 0.660 & 0.452 & 0.451 & 0.520 & 0.363 \\
\hline Fs & 0.306 & 0.486 & 0.383 & 0.317 & 0.271 & 0.294 & 0.208 & 0.185 & 0.440 & 0.233 \\
\hline \multirow[t]{2}{*}{ Wo } & 0.401 & 0.161 & 0.299 & 0.075 & 0.380 & 0.046 & 0.339 & 0.364 & 0.039 & 0.404 \\
\hline & column 16 & column 17 & column 18 & column 19 & column 20 & column 21 & column 22 & column 23 & column 24 & column 25 \\
\hline$\# \mathrm{Si}^{4+}$ & 1.934 & 1.934 & 1.915 & 1.956 & 1.971 & 1.948 & 1.940 & 1.957 & 2.038 & 1.886 \\
\hline$\# \mathrm{Ti}^{4+}$ & 0.016 & 0.007 & 0.012 & 0.006 & 0.006 & 0.009 & 0.008 & 0.003 & 0.001 & 0.015 \\
\hline$\# \mathrm{Al}^{3+}$ & 0.077 & 0.060 & 0.088 & 0.039 & 0.040 & 0.075 & 0.078 & 0.212 & 0.116 & 0.110 \\
\hline$\# \mathrm{Cr}^{3+}$ & 0.000 & 0.000 & 0.000 & 0.000 & 0.000 & 0.001 & 0.000 & 0.000 & 0.000 & 0.001 \\
\hline$\# \mathrm{Fe}^{2+}$ & 0.539 & 0.250 & 0.275 & 0.519 & 0.513 & 0.421 & 0.413 & 0.689 & 0.657 & 0.510 \\
\hline$\# \mathrm{Mn}^{2+}$ & 0.016 & 0.013 & 0.016 & 0.020 & 0.017 & 0.008 & 0.009 & 0.041 & 0.040 & 0.015 \\
\hline$\# \mathrm{Mg}^{2+}$ & 0.815 & 0.827 & 0.795 & 1.409 & 1.400 & 1.518 & 1.534 & 0.554 & 0.612 & 0.825 \\
\hline$\# \mathrm{Ca}^{2+}$ & 0.585 & 0.885 & 0.873 & 0.049 & 0.050 & 0.019 & 0.018 & 0.518 & 0.521 & 0.622 \\
\hline$\# \mathrm{Na}^{1+}$ & 0.017 & 0.023 & 0.026 & 0.002 & 0.003 & 0.001 & 0.001 & 0.025 & 0.015 & 0.015 \\
\hline \#TOTAL & 4.000 & 4.000 & 4.000 & 4.000 & 4.000 & 4.000 & 4.000 & 4.000 & 4.000 & 4.000 \\
\hline$\Sigma \mathrm{MgFeCa}^{2+}$ & 1.939 & 1.962 & 1.943 & 1.977 & 1.962 & 1.958 & 1.965 & 1.762 & 1.790 & 1.957 \\
\hline En & 0.420 & 0.422 & 0.409 & 0.713 & 0.713 & 0.775 & 0.781 & 0.315 & 0.342 & 0.422 \\
\hline Fs & 0.278 & 0.127 & 0.142 & 0.262 & 0.261 & 0.215 & 0.210 & 0.391 & 0.367 & 0.261 \\
\hline \multirow[t]{2}{*}{ Wo } & 0.302 & 0.451 & 0.449 & 0.025 & 0.026 & 0.010 & 0.009 & 0.294 & 0.291 & 0.318 \\
\hline & column 26 & column 27 & column 28 & column 29 & column 30 & column 31 & column 32 & column 33 & column 34 & column 35 \\
\hline$\# \mathrm{Si}^{4+}$ & 1.932 & 1.941 & 1.941 & 1.952 & 1.923 & 1.918 & 1.943 & 1.952 & 1.951 & 1.966 \\
\hline$\# \mathrm{Ti}^{4+}$ & 0.007 & 0.007 & 0.005 & 0.009 & 0.010 & 0.006 & 0.007 & 0.011 & 0.005 & 0.006 \\
\hline$\# \mathrm{Al}^{3+}$ & 0.043 & 0.045 & 0.043 & 0.041 & 0.044 & 0.100 & 0.070 & 0.036 & 0.024 & 0.024 \\
\hline$\# \mathrm{Cr}^{3+}$ & 0.000 & 0.000 & 0.000 & 0.000 & 0.000 & 0.005 & 0.001 & 0.002 & 0.000 & 0.000 \\
\hline$\# \mathrm{Fe}^{2+}$ & 0.717 & 0.741 & 0.745 & 0.804 & 0.743 & 0.263 & 0.581 & 0.924 & 0.926 & 0.917 \\
\hline \# $\mathrm{Mn}^{2+}$ & 0.022 & 0.019 & 0.020 & 0.024 & 0.022 & 0.009 & 0.014 & 0.024 & 0.031 & 0.026 \\
\hline$\# \mathrm{Mg}^{2+}$ & 1.065 & 1.038 & 1.043 & 0.976 & 0.910 & 0.894 & 1.174 & 0.832 & 0.986 & 0.983 \\
\hline$\# \mathrm{Ca}^{2+}$ & 0.210 & 0.203 & 0.198 & 0.189 & 0.338 & 0.793 & 0.205 & 0.213 & 0.077 & 0.075 \\
\hline$\# \mathrm{Na}^{\mathrm{I+}}$ & 0.005 & 0.006 & 0.004 & 0.005 & 0.010 & 0.011 & 0.005 & 0.005 & 0.000 & 0.002 \\
\hline \#TOTAL & 4.000 & 4.000 & 4.000 & 4.000 & 4.000 & 4.000 & 4.000 & 4.000 & 4.000 & 4.000 \\
\hline$\Sigma \mathrm{MgFeCa}^{2+}$ & 1.992 & 1.982 & 1.986 & 1.969 & 1.991 & 1.950 & 1.960 & 1.970 & 1.989 & 1.976 \\
\hline En & 0.535 & 0.524 & 0.525 & 0.496 & 0.457 & 0.458 & 0.599 & 0.423 & 0.496 & 0.498 \\
\hline Fs & 0.360 & 0.374 & 0.375 & 0.408 & 0.373 & 0.135 & 0.296 & 0.469 & 0.465 & 0.464 \\
\hline \multirow[t]{2}{*}{ Wo } & 0.106 & 0.102 & 0.100 & 0.096 & 0.170 & 0.407 & 0.105 & 0.108 & 0.039 & 0.038 \\
\hline & column 31 & column 32 & column 33 & column 34 & column 35 & column 36 & column 37 & column 38 & column 39 & column 40 \\
\hline$\# \mathrm{Si}^{4+}$ & 1.918 & 1.943 & 1.952 & 1.951 & 1.966 & 1.944 & 1.937 & 1.956 & 1.942 & 1.913 \\
\hline$\# \mathrm{Ti}^{4+}$ & 0.006 & 0.007 & 0.011 & 0.005 & 0.006 & 0.008 & 0.008 & 0.007 & 0.008 & 0.014 \\
\hline$\# \mathrm{Al}^{3+}$ & 0.100 & 0.070 & 0.036 & 0.024 & 0.024 & 0.042 & 0.048 & 0.030 & 0.048 & 0.136 \\
\hline$\# \mathrm{Cr}^{3+}$ & 0.005 & 0.001 & 0.002 & 0.000 & 0.000 & 0.000 & 0.000 & 0.001 & 0.001 & 0.000 \\
\hline$\# \mathrm{Fe}^{2+}$ & 0.263 & 0.581 & 0.924 & 0.926 & 0.917 & 0.476 & 0.482 & 0.930 & 0.477 & 0.461 \\
\hline$\# \mathrm{Mn}^{2+}$ & 0.009 & 0.014 & 0.024 & 0.031 & 0.026 & 0.016 & 0.018 & 0.031 & 0.016 & 0.016 \\
\hline$\# \mathrm{Mg}^{2+}$ & 0.894 & 1.174 & 0.832 & 0.986 & 0.983 & 0.677 & 0.687 & 0.963 & 0.693 & 0.790 \\
\hline$\# \mathrm{Ca}^{2+}$ & 0.793 & 0.205 & 0.213 & 0.077 & 0.075 & 0.818 & 0.803 & 0.077 & 0.800 & 0.654 \\
\hline$\# \mathrm{Na}^{1+}$ & 0.011 & 0.005 & 0.005 & 0.000 & 0.002 & 0.018 & 0.018 & 0.005 & 0.016 & 0.015 \\
\hline \#TOTAL & 4.000 & 4.000 & 4.000 & 4.000 & 4.000 & 4.000 & 4.000 & 4.000 & 4.000 & 4.000 \\
\hline$\Sigma \mathrm{MgFeCa}^{2+}$ & 1.950 & 1.960 & 1.970 & 1.989 & 1.976 & 1.971 & 1.972 & 1.970 & 1.970 & 1.905 \\
\hline En & 0.458 & 0.599 & 0.423 & 0.496 & 0.498 & 0.343 & 0.348 & 0.489 & 0.352 & 0.415 \\
\hline Fs & 0.135 & 0.296 & 0.469 & 0.465 & 0.464 & 0.242 & 0.245 & 0.472 & 0.242 & 0.242 \\
\hline Wo & 0.407 & 0.105 & 0.108 & 0.039 & 0.038 & 0.415 & 0.407 & 0.039 & 0.406 & 0.343 \\
\hline
\end{tabular}


Table 3 (continued).

\begin{tabular}{|c|c|c|c|c|c|c|}
\hline & column 41 & column 42 & column 43 & column 44 & column 45 & column 46 \\
\hline$\# \mathrm{Si}^{4+}$ & 1.792 & 1.772 & 1.954 & 1.946 & 1.734 & 1.734 \\
\hline$\# \mathrm{Ti}^{4+}$ & 0.027 & 0.028 & 0.008 & 0.008 & 0.034 & 0.036 \\
\hline$\# \mathrm{Al}^{3+}$ & 0.275 & 0.282 & 0.066 & 0.062 & 0.319 & 0.322 \\
\hline$\# \mathrm{Cr}^{3+}$ & 0.000 & 0.000 & 0.000 & 0.000 & 0.000 & 0.000 \\
\hline$\# \mathrm{Fe}^{2+}$ & 0.439 & 0.469 & 0.750 & 0.765 & 0.508 & 0.499 \\
\hline \# $\mathrm{Mn}^{2+}$ & 0.011 & 0.013 & 0.025 & 0.025 & 0.011 & 0.009 \\
\hline$\# \mathrm{Mg}^{2+}$ & 0.666 & 0.670 & 0.964 & 1.005 & 0.647 & 0.637 \\
\hline${\# \mathrm{Ca}^{2+}}^{2+}$ & 0.770 & 0.746 & 0.227 & 0.186 & 0.732 & 0.747 \\
\hline$\# \mathrm{Na}^{1+}$ & 0.019 & 0.019 & 0.006 & 0.004 & 0.015 & 0.015 \\
\hline \#TOTAL & 4.000 & 4.000 & 4.000 & 4.000 & 4.000 & 4.000 \\
\hline$\Sigma \mathrm{MgFeCa}^{2+}$ & 1.876 & 1.885 & 1.942 & 1.956 & 1.888 & 1.882 \\
\hline En & 0.355 & 0.355 & 0.496 & 0.514 & 0.343 & 0.338 \\
\hline Fs & 0.234 & 0.249 & 0.386 & 0.391 & 0.269 & 0.265 \\
\hline Wo & 0.411 & 0.396 & 0.117 & 0.095 & 0.388 & 0.397 \\
\hline
\end{tabular}

A, as wt\% oxides; B, in terms of cation proportions on the basis of six oxygen atoms, and end-member enstatite (En), ferrosilite (Fs) and wollastonite (Wo) proportions. $\Sigma \mathrm{MgFeCa}^{2+}$ refers to the sum of $\mathrm{Mg}$, $\mathrm{Fe}$ and $\mathrm{Ca}$ cations. Total $\mathrm{Fe}$ reported as $\mathrm{FeO}$. Column numbers refer to the following ash layers, from which the specific pyroxene analyses were made: $1-3,125-782 \mathrm{~A}-13 \mathrm{X}-3,52-54 \mathrm{~cm} ; 4-8,125-782 \mathrm{~A}$ $17 \mathrm{X}-2,123-125 \mathrm{~cm} ; 9-16,125-782 \mathrm{~A}-17 \mathrm{X}-5,140-142 \mathrm{~cm} ; 17-20,125-784 \mathrm{~A}-9 \mathrm{R}-1,69-71 \mathrm{~cm} ; 21-24$. 125-784A-17R-3, 144-149 cm; 25, 125-784A-20R-3, 67-69 cm; 26-33, 125-786A-7X-3, 15-17 cm; $34-39,125-786 \mathrm{~A}-9 \mathrm{X}-3,129-131 \mathrm{~cm} ; 40-46,125-786 \mathrm{~A}-9 \mathrm{X}-4,24-26 \mathrm{~cm}$.

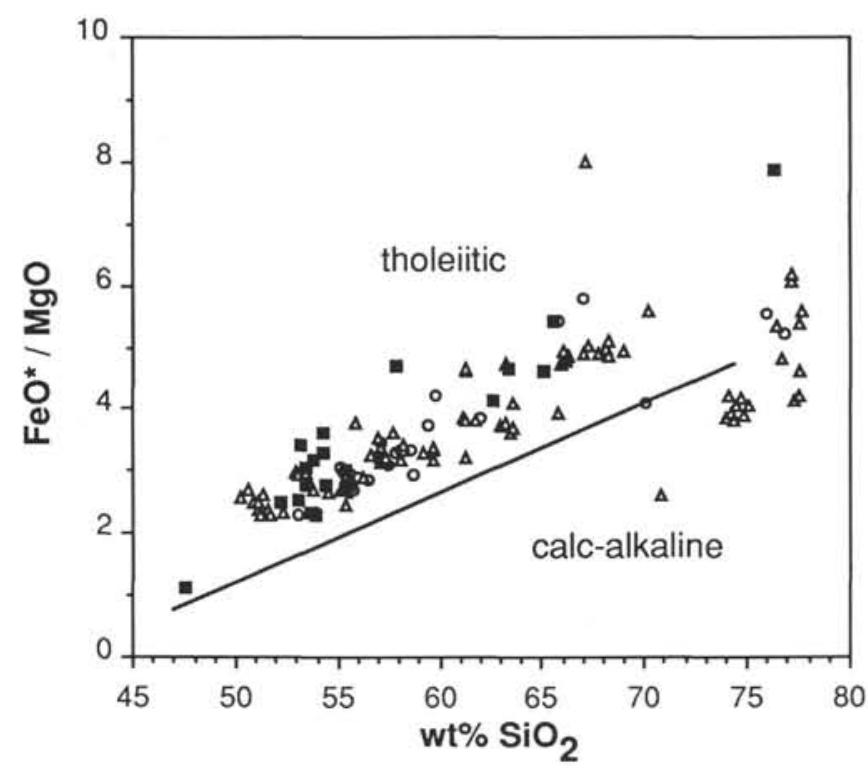

Figure 3. Variation of $\mathrm{FeO}^{*}$ (total $\mathrm{Fe}$ as $\mathrm{FeO}$ )/MgO vs. $\mathrm{SiO}_{2}$ for all ash compositions. Discriminant line between tholeiitic and calc-alkaline compositions is from Miyashiro (1974). In this figure and also Figures 4 and 5, symbols are as follows: Hole 782A, circles; Hole 784A, triangles; Hole 786A, squares.

For homogeneous ash layers and consistent pyroxene assemblage compositions, the thermometer of Lindsley (1983) was applied with the assumptions (1) that the separate clinopyroxene and orthopyroxene crystal components were in equilibrium and (2) that an equilibration pressure of $10^{5} \mathrm{~Pa}$ is appropriate. Both assumptions may be invalid, and further comparative study of pyroxenes within glasses and the isolated crystals will be required. Preliminary results give a range of equilibration temperatures from about $1050^{\circ} \mathrm{C}$ for the analyzed ash layer from 125-782A-17X-2, 123-125 cm ( 56 wt\% $\mathrm{SiO}_{2}$ ), to $780^{\circ} \mathrm{C}$ for the layer from $125-786 \mathrm{~A}-9 \mathrm{X}-3,129-131 \mathrm{~cm}$ ( 76 wt\% $\left.\mathrm{SiO}_{2}\right)$.
A notable absence from the ashes analyzed so far is any boninitic or bronzite andesite component. Warner et al. (1987) recognized such compositions in ashes recovered from the Mariana Trough. It would appear that a pulse of intermediate- $\mathrm{Ca}$ and high-Ca boninite (terms defined in Arculus et al., this volume) dike intrusion took place at about $34 \mathrm{Ma}$ in the FBH as recovered from Hole 786B (see Mitchell et al. and Pearce et al., this volume). Our ash sampling density may not have been sufficient to identify such compositions, especially if they erupted over a limited time span; however, such materials may yet be discovered.

Clearly, the ash suite examined to date is distinctive compositionally with respect to (1) the igneous lithologies recovered from the basement underlying Holes 782A and 786A; and (2) the lithologies present in the currently active subaerial arc volcanoes of Torishima and Sumisu Jima (Fig. 7). The relatively high $\mathrm{TiO}_{2}$ concentrations at low $\mathrm{SiO}_{2}$ abundances of the ash sequence is a particularly striking difference and can be attributed to the involvement of a more-fertile upper mantle source than that associated with both the FBH sites and the currently active subaerial arc. In fact, we observed that with $\mathrm{TiO}_{2}$ concentrations of about $1.5 \mathrm{wt} \%$ at $50 \mathrm{wt} \% \mathrm{SiO}_{2}$, the ash sequence overlaps most closely with the relatively young eruptive products from the actively spreading backarc basin to the west of Sumisu Jima. Our current working hypotheses are (1) that across-strike chemical variations in the nature of the upper mantle are tapped at different times during magma generation episodes in the evolution of the overall arc basement and (2) that these variations are relatively long-lived, sometimes escaping general replenishment by advective processes in the mantle wedge overlying subjacent, subducted lithosphere.

\section{CONCLUSIONS}

From an initial study of a representative set of vitric ashes recovered from sedimentary sequences (mostly nannofossil-bearing calcareous marls and clays) overlying the forearc basement of the Bonin arc, the following conclusions can be drawn: (1) the geochemistry of these ashes is remarkably consistent, with very limited spread around a basalt-torhyolite spectrum; (2) the sequences belong to a low-K tholeiitic suite; (3) the compositions are coincident with experimentally-determined, atmospheric-pressure cotectics and peritectics; (4) there is no indication of a secular evolution of the chemistry of these ashes of increasing 

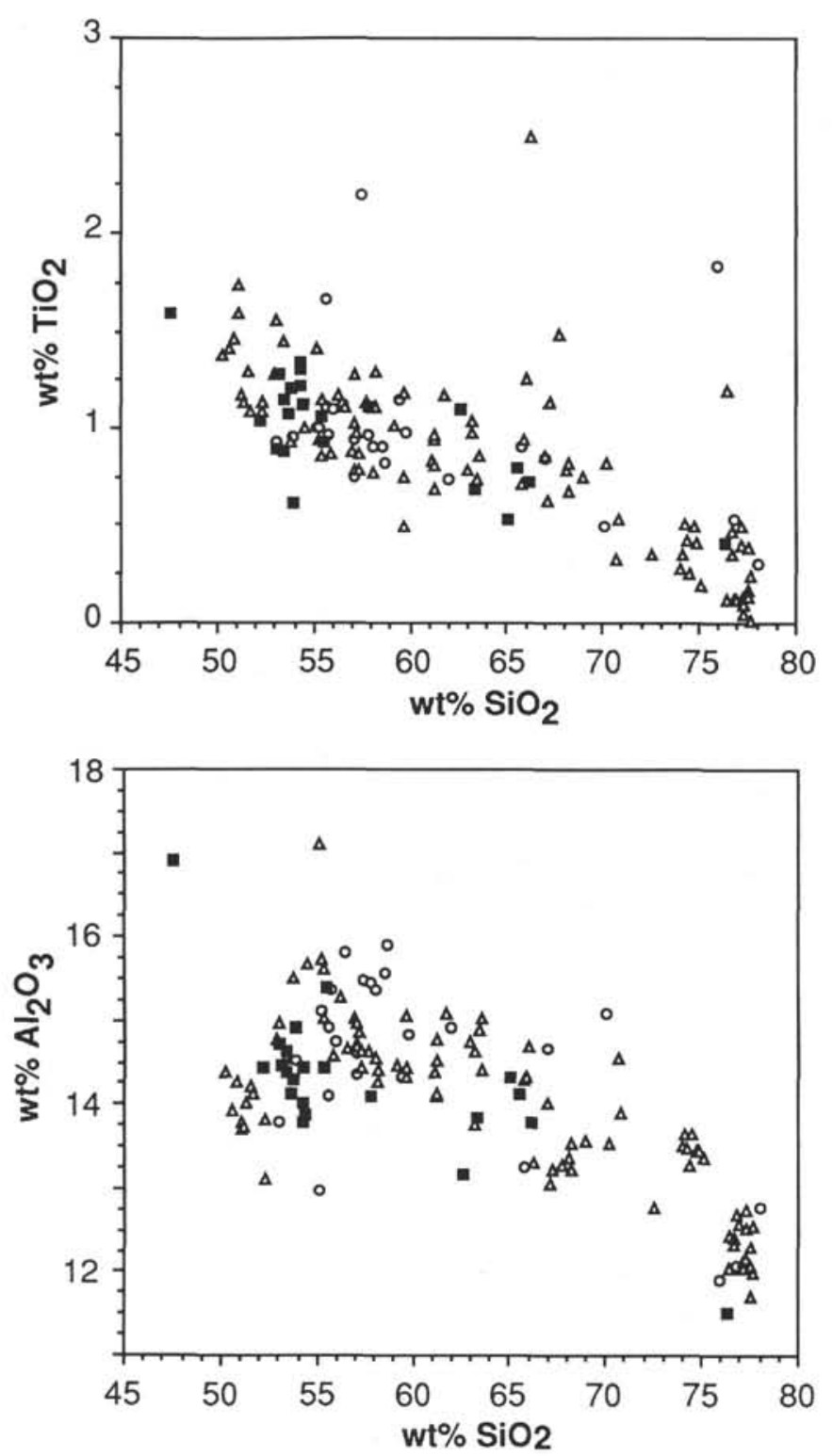

Figure 4. Variation of wt $\%$ oxides vs. wt $\% \mathrm{SiO}_{2}$ for all ashes, distinguished by Site.

alkalinity with time, in sharp contradiction with many popular models of the magmatic evolution of island arcs; (5) the volumetrically predominant crystalline phases are orthopyroxene and clinopyroxene and plagioclase. Hydrous silicates are absent; and (6) the geochemistry of the ashes is distinctly different, compared to the igneous basement that formed the present $\mathrm{FBH}$; clearly, different sources in the upper mantle have been involved.

\section{ACKNOWLEDGMENTS}

Floyd McCoy was the on-board inspiration for this study. USSAC provided logistic support for A.L.B. and funds for analytical costs at the University of Michigan. Other expenses have been covered by Australian Research Council Grant A39030242 and a University of New England Internal Research Grant to R.J.A. The major contributions of all ship-
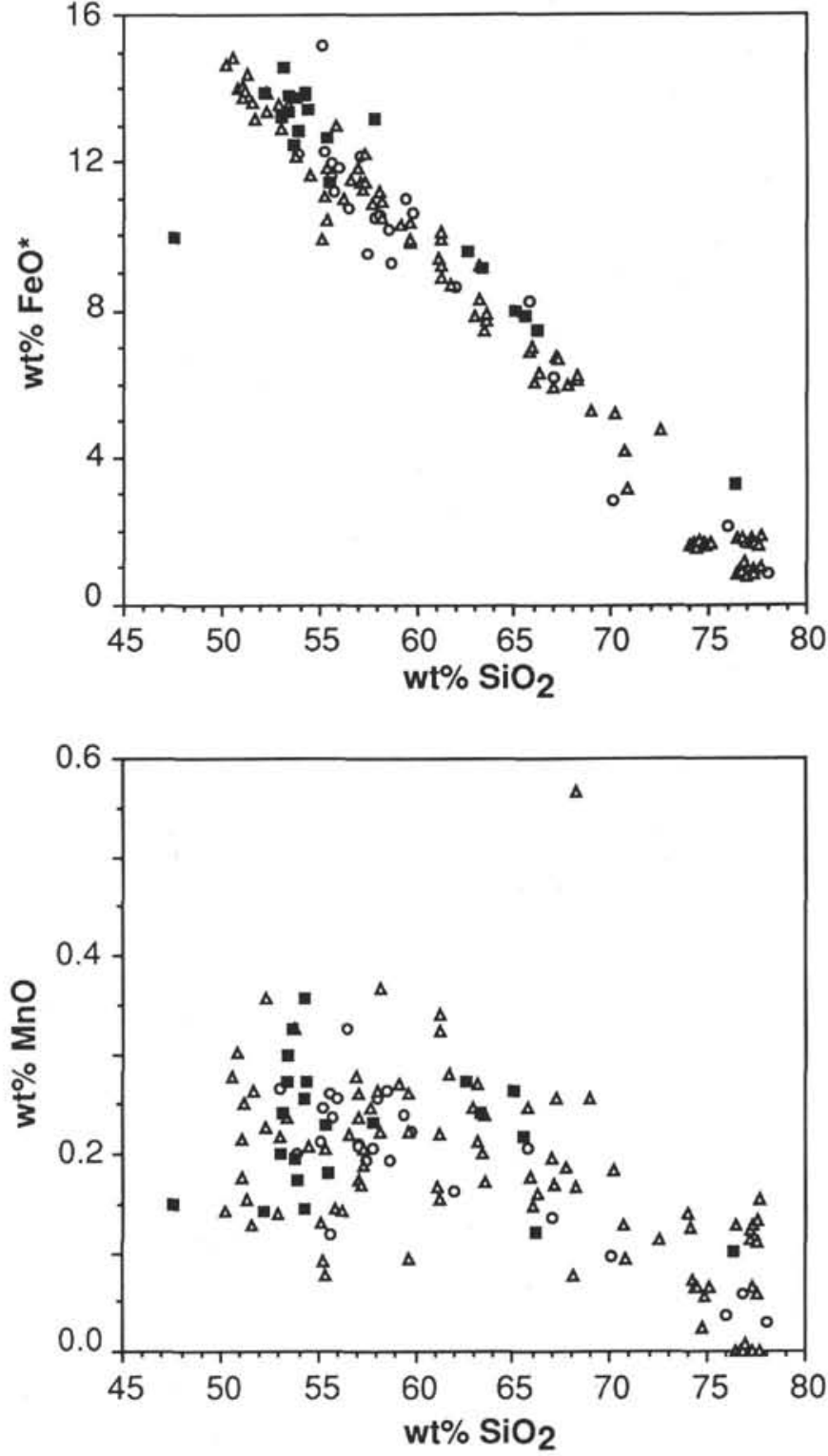

board scientists, technicians and crew to the success of Leg 125 are much appreciated. R. Varne and an anonymous reviewer provided insightful criticism of a preliminary version of this manuscript.

\section{REFERENCES}

Clemens, J. D., 1984. Water contents of silicic to intermediate magmas. Lithos, 17:273-287.

Grove, T. L., Gerlach, D. C., and Sando, T. W., 1982. Origin of calc-alkaline series lavas at Medicine Lake Volcano by fractionation, assimilation and mixing. Contrib. Mineral. Petrol., 80:160-182.

Honza, E., and Tamaki, K., 1985. The Bonin Arc. In Nairn, A.E.M, and Uyeda, S. (Eds.), The Ocean Basins and Margins (Vol. 7): New York (Plenum), 459-502.

Jercinovic, M. J., Keil, K., 1988. Electron microprobe analysis of basaltic glasses and associated alteration products. Microbeam Anal., 1988:495-497. 

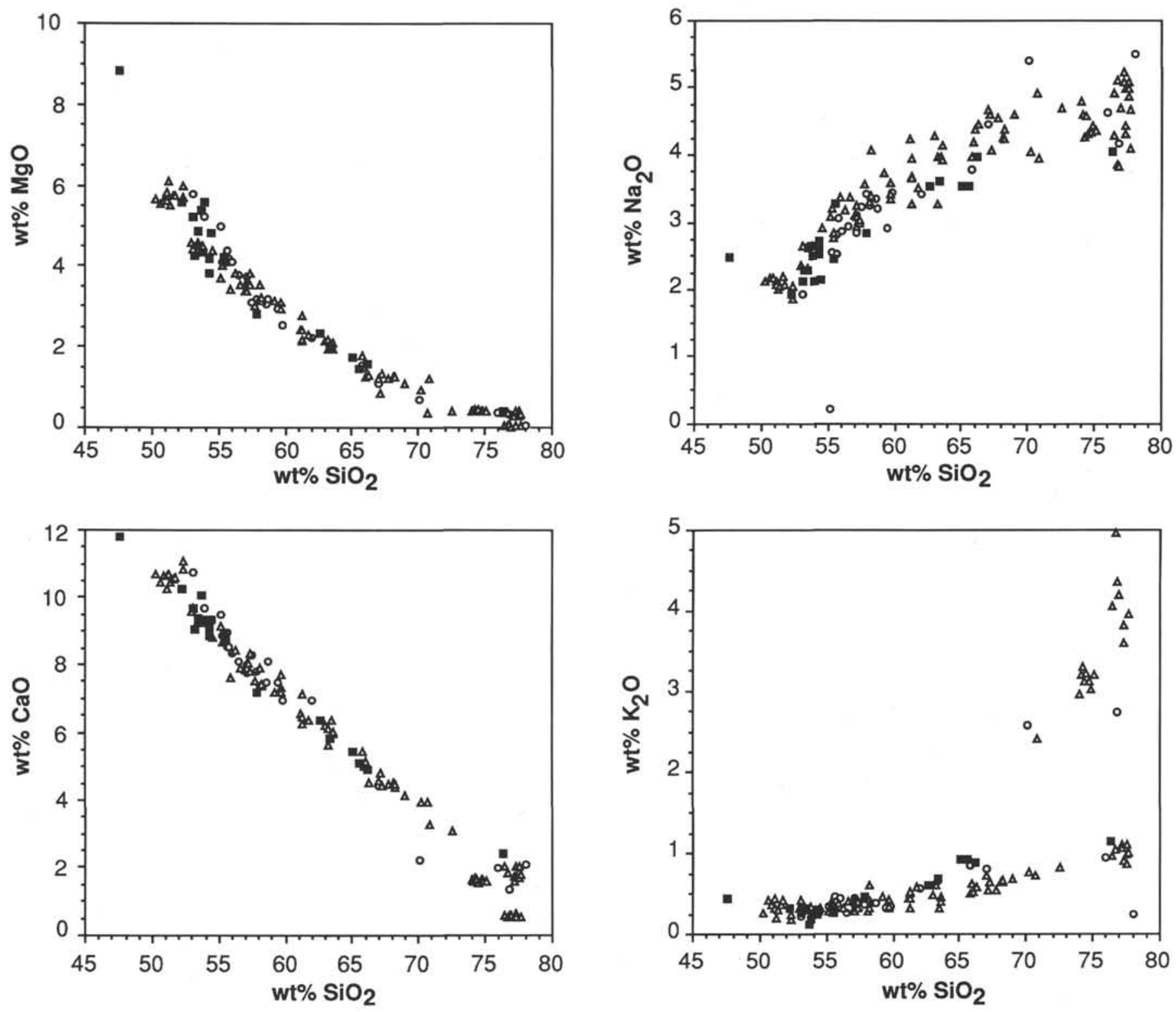

Figure 4 (continued).

Lindsley, D. H., 1983. Pyroxene thermometry. Am. Mineral., 68:477-493. Miyashiro, A., 1974. Volcanic rock series in island arcs and active continental margins. Am. J. Sci., 274:321-355.

Neilson, C. H., Sigurdsson. H., 1981. Quantitative methods for electron microprobe analysis of sodium in natural and synthetic glasses. Am. Mineral., 66:547-552.

Strope, M. B., 1984. A method of combating alkali metal loss during microbeam analysis of basaltic glass. Microbeam Anal., 154-156.
Warner, R. J., Flower, M.F.J., and Rodolfo, K. S., 1987. Geochemical evidence for sundering of the west Mariana arc in Miocene ash from the Parece Vela Basin. J. Volcan. Geotherm. Res., 33:263-281.

Date of initial receipt: 1 October 1990

Date of acceptance: 8 July 1991

Ms 125B-149 

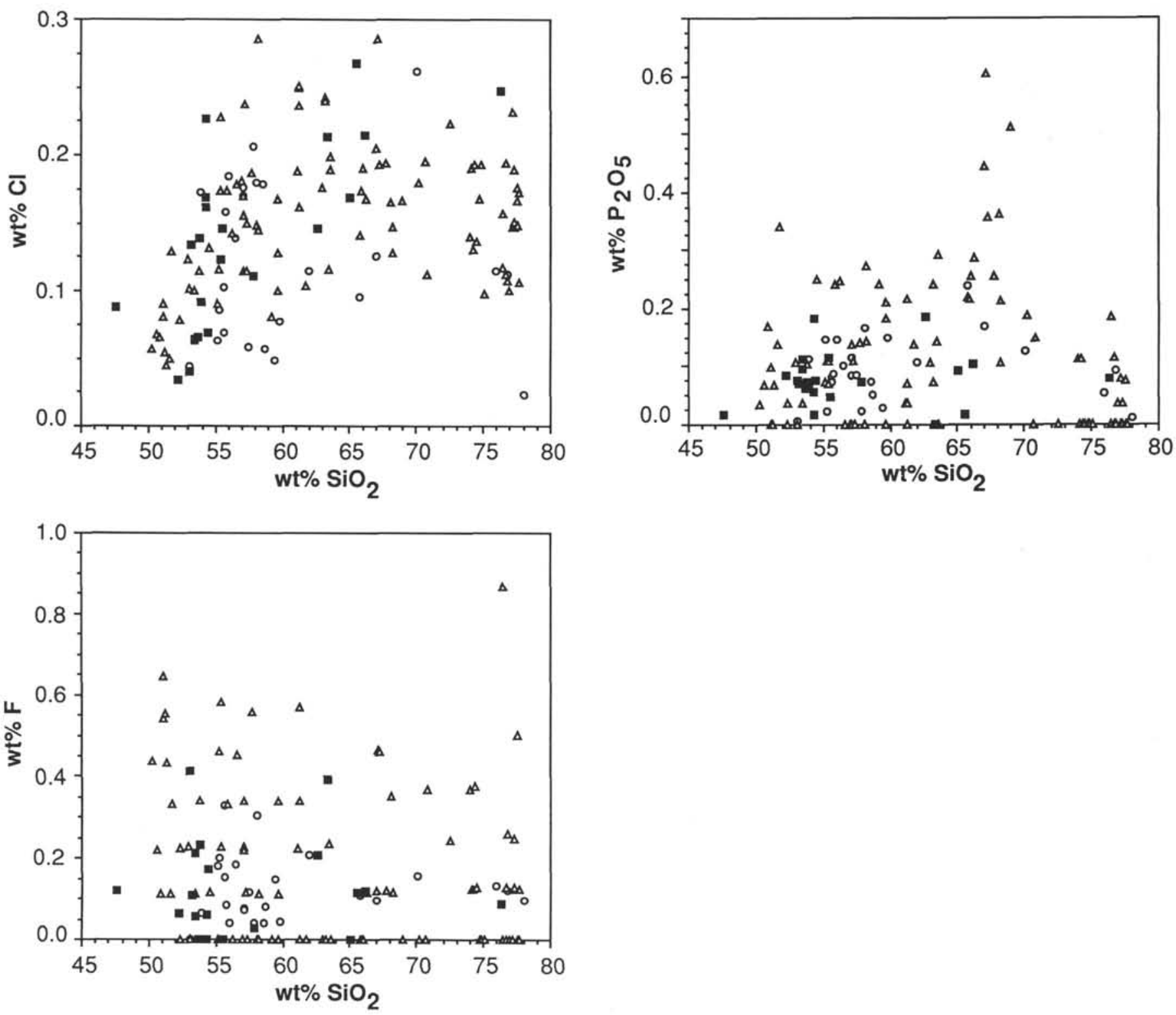

Figure 4 (continued). 


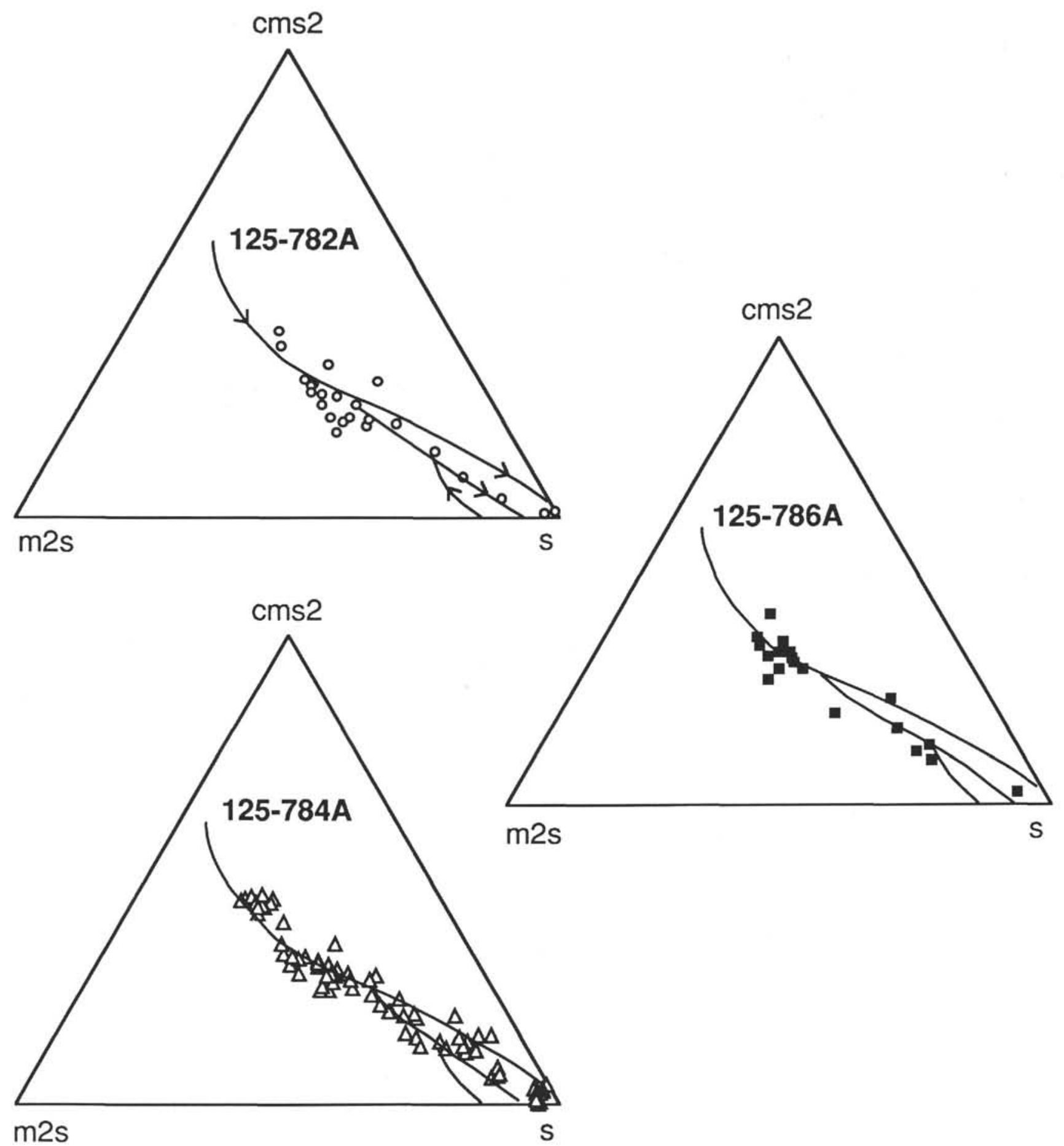

Figure 5. Oxygen-weighted molar projections of ash compositions (grouped and also distinguished by individual site) in the pseudoternary clinopyroxene (cms2)-olivine (m2s)- $\mathrm{SiO}_{2}(\mathrm{~s})$, after Grove et al. (1982); $10^{5} \mathrm{~Pa}$ cotectics and peritectics are indicated. 

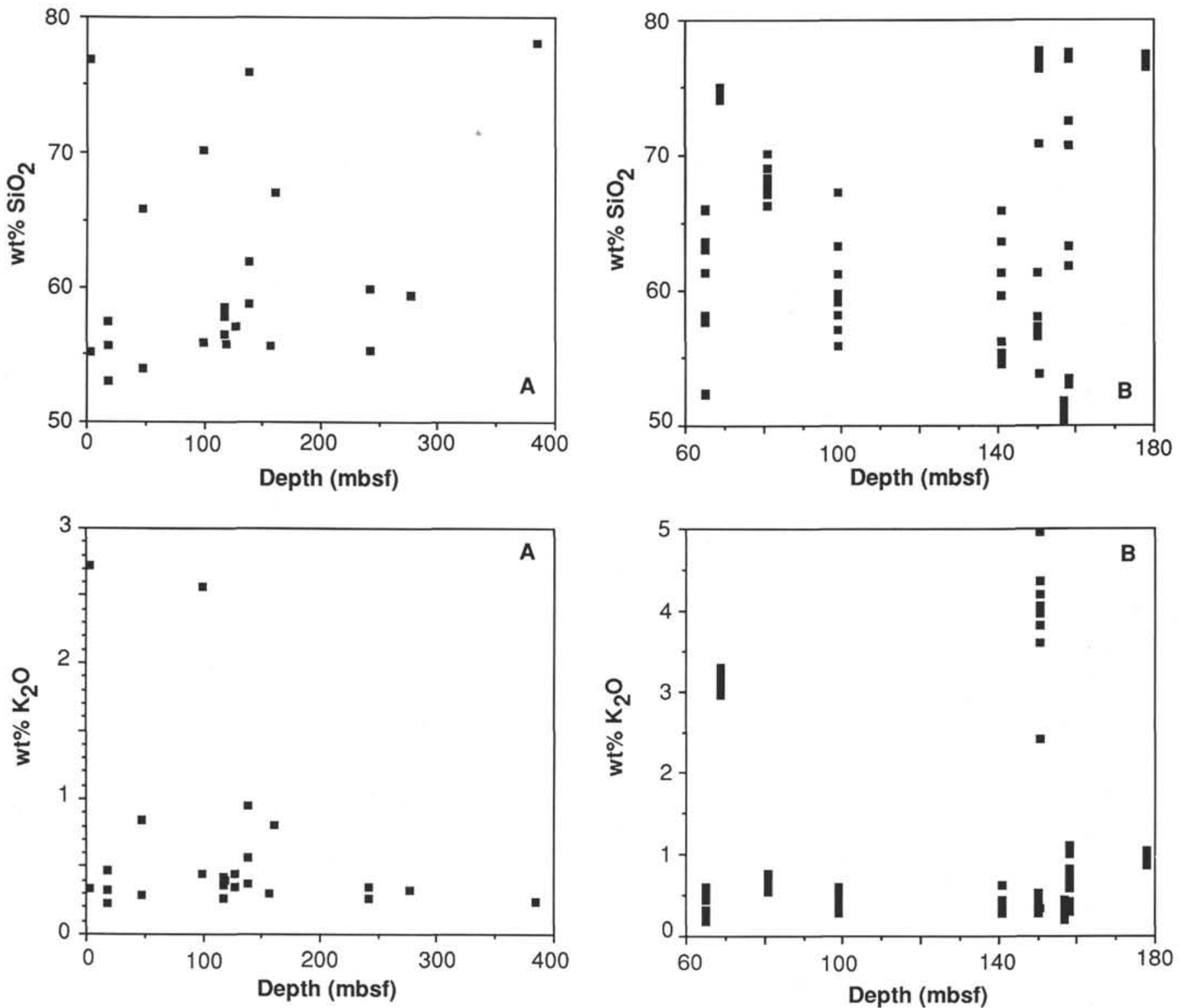

Figure 6. Oxide variations of ash compositions plotted against depth (in meters) below seafloor (mbsf). A. Site 782, B. Site 784, C. Site 786. 

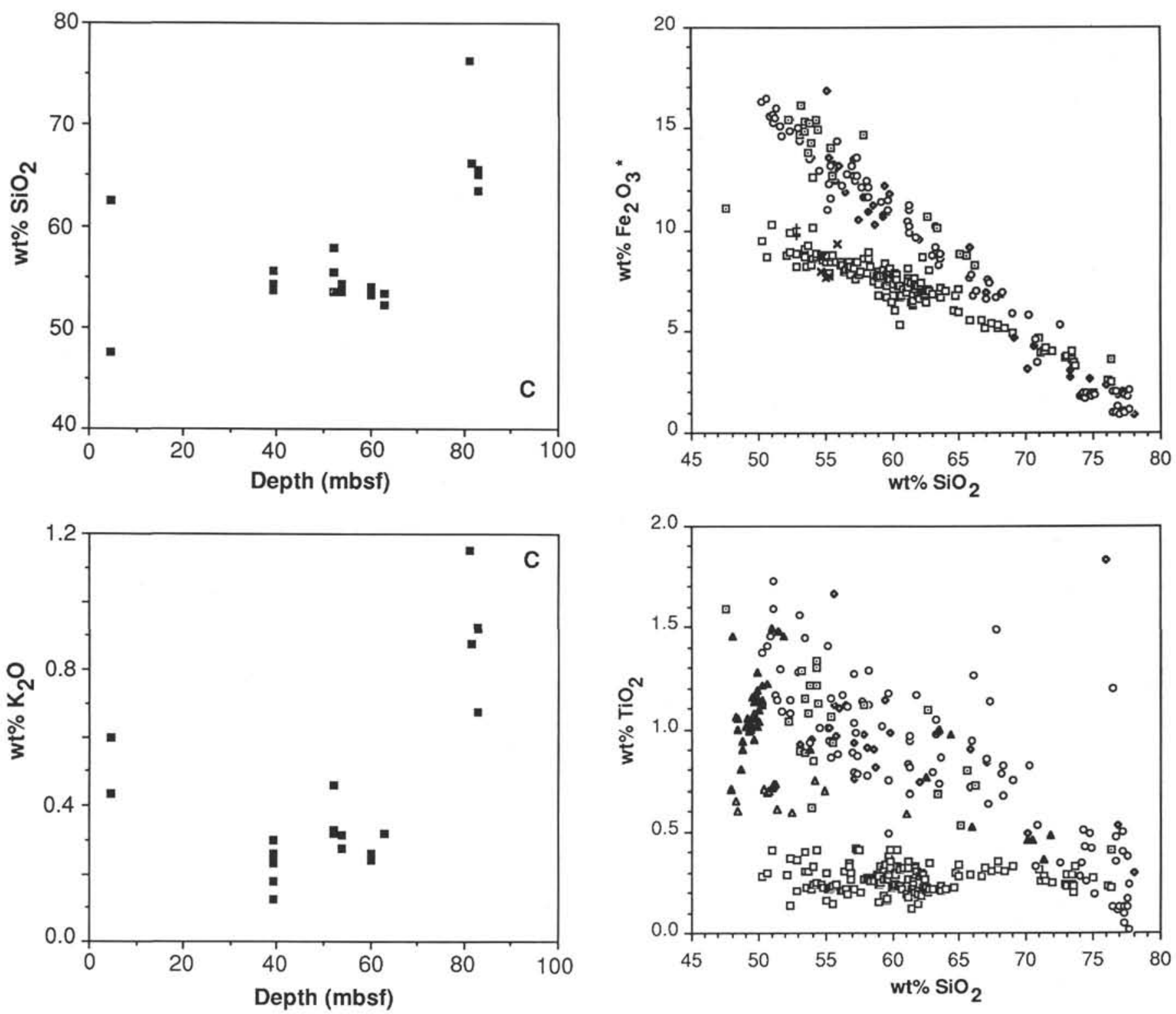

Figure 6 (continued).

Figure 7. Comparison of ash chemistry to lithologies from the forearc basement high (recovered at Sites 782 and 786, see Arculus et al., this volume) and active subaerial Bonin arc volcanoes (Torishima and Sumisu Jima). Symbols are as follows: igneous basement lithologies from Site 125-786, open squares; igneous basement from Site 125-782, filled diamonds; igneous basement from Hole 126-793B, multiplication signs; sill from Hole 126-793A, plus signs; ash layers from Hole 125-782A, open diamonds; ash layers from Hole 125-784A, open circles; ash layers from Hole 786A, dotted squares; open triangles, active subaerial volcanoes; filled triangles, backarc rift. 